\title{
Genomic imprinting and its effects on postnatal growth and adult metabolism
}

\author{
Steven J. Millership ${ }^{1,2} \cdot$ Mathew Van de Pette ${ }^{1,2} \cdot$ Dominic J. Withers ${ }^{1,2} \mathbb{C}$
}

Received: 16 April 2019 / Revised: 10 June 2019 / Accepted: 17 June 2019 / Published online: 3 July 2019

(C) The Author(s) 2019

\begin{abstract}
Imprinted genes display parent-of-origin-specific expression with this epigenetic system of regulation found exclusively in therian mammals. Historically, defined imprinted gene functions were almost solely focused on pregnancy and the influence on the growth parameters of the developing embryo and placenta. More recently, a number of postnatal functions have been identified which converge on resource allocation, both for animals in the nest and in adults. While many of the prenatal functions of imprinted genes that have so far been described adhere to the "parental conflict" hypothesis, no clear picture has yet emerged on the functional role of imprints on postnatal metabolism. As these roles are uncovered, interest in the potential for these genes to influence postnatal metabolism and associated adult-onset disease outcomes when dysregulated has gathered pace. Here, we review the published data on imprinted genes and their influence on postnatal metabolism, starting in the nest, and then progressing through to adulthood. When observing the functional effects of these genes on adult metabolism, we must always be careful to acknowledge the influence both of direct expression in the relevant metabolic tissue, but also indirect metabolic programming effects caused by their modulation of both in utero and postnatal growth trajectories.
\end{abstract}

Keywords Metabolic programming $\cdot$ Mouse models $\cdot$ Maternal care $\cdot$ Environment $\cdot$ Diet $\cdot$ Obesity

\section{Introduction}

Genomic imprinting is an epigenetic phenomenon resulting in parent-of-origin-specific gene expression [1-3] in therian mammals. Pioneering experiments using parthenogenetic and androgenetic embryos demonstrated an absolute requirement for both of the parentally inherited genomes, implicating a genetic imbalance between the two and paving the way for the subsequent discovery of imprinted genes. Currently, around 150 genes have been demonstrated as imprinted and they show a large degree of overlap between mice and humans. Many of these are found in genomic clusters, each with an epigenetically regulated imprinting control region (ICR) $[4,5]$ that is, in effect, a differentially

Steven J. Millership

s.millership@imperial.ac.uk

$\triangle$ Dominic J. Withers

d.withers@imperial.ac.uk

1 MRC London Institute of Medical Sciences, Du Cane Road, London W12 0NN, UK

2 Institute of Clinical Sciences, Faculty of Medicine, Imperial College London, Du Cane Road, London W12 0NN, UK methylated region (DMR). Epigenetic marks including DNA methylation (at $\mathrm{CpG}$ dinucleotides, often found in clusters or CpG 'islands') and histone tail modifications (found at promoters or gene bodies), are initiated in the germline during development and maintained in the developing embryo and throughout postnatal lifespan. Most imprinted loci have been demonstrated to possess multiple layers of epigenetic control allowing appropriate expression of the active, but not silent allele. These mechanisms of regulation are beyond the scope of this article and have been extensively reviewed previously [6-9].

The development and subsequent expansion of the imprinting system may have evolved as a consequence of 'parental conflict' in response to selective pressures uniquely encountered by a pregnancy. This hypothesis [10] suggests a difference in the interests of the maternal and paternal genome, whereby females, who are related to all of her offspring, aim to conserve maternal resources over multiple litters and pups. In contrast, with possible multiple paternity across litters, and therefore as it is not necessarily related to other offspring of the mother, the opportunistic paternal genome seeks to extract maximal maternal resources. In keeping with this hypothesis, paternally expressed genes 
(PEGs) are generally growth promoting, whereas maternally expressed genes (MEGs) are growth restricting [11]. A second hypothesis, the co-adaptation model of genetic symbiosis between mother and offspring, has also been proposed [12]. This suggests that monoallelic expression of imprinted genes arose to achieve maximal efficiency of offspring development, via maternal care inputs and also directly in the offspring, and is discussed later in more detail. However, as our knowledge of imprinted gene function has expanded, we have observed an increasing number of "outlier" imprinted genes which do not obviously fit within these expected patterns, suggesting that other evolutionary pressures beyond conflicting parental genomes or co-adaptation have led to the broadening of this method of gene regulation. Interestingly, this method of gene dosage control is not exclusively a mammalian phenomenon, with evolutionary isolated systems having been observed in plants and possibly birds $[13,14]$. Alongside X-chromosome inactivation, a distinct form of regulating appropriate dosage from the sex chromosomes in mammals, these methods of epigenetic regulation, whether silencing an allele or chromosome, presumably provide an advantageous phenotype, regardless of any perceived dangers associated with functionally possessing monoallelic rather than biallelic genes, i.e. masking of deleterious mutations.

Monoallelic imprinted genes are therefore subject to vulnerability in terms of gene dosage not normally encountered by non-imprinted loci, highlighted by the fact that altered imprinted gene expression is associated with a wide range of human disorders that can be modelled with specific gene modifications in mice. Prader-Willi, Angelman, Silver-Russell, Beckwith-Wiedemann syndromes and transient neonatal diabetes all result from abnormalities in the expression of specific imprinted genes (reviewed in $[15,16]$ ). With the likely exception of Angelman syndrome, believed to be caused exclusively by the loss of expression of the $U B E 3 A$ gene, many of these so-called imprinting disorders arise as a result of altered expression of a cluster of genes sharing the same epigenetic control, with consequent loss of expression or increased dosage of affected genes. Consistent with the roles of imprinted genes in key processes such as growth, metabolism and behaviour, these disorders result in a range of clinical features including aberrant pre- and/ or postnatal growth, abnormal feeding behaviour, learning difficulties and metabolic complications [16]. Discovery of these genetic modifications, and the conditions associated with them, has led to the necessary task of picking apart the individual contributions of various genes in these clusters, made more difficult by the intrinsic epigenetic mechanisms in place regulating imprinted (and non-imprinted) genes across the same genomic region. Even so, the clinical features described in patients with these conditions are generally consistent with those observed in mouse models.
Although imprinted genes display a variety of cellular roles (cell cycle control, ion channels, protein synthesis and degradation and nutrient transport), their expression frequently shares common features of having maximal levels during the prenatal and/or postnatal period, and occurring predominantly in tissues governing resource allocation (brain, placenta, adipose tissue and pancreatic beta cells). It is, therefore, not surprising that a substantial number of imprinted genes are critical for placental function and normal fetal growth and development [17-20]. These roles extend to a wide range of processes vital for survival and development postnatally, including thermoregulation, feeding behaviour and regulation of glucose and lipid metabolism [21-31].

To understand these diverse roles, a number of different approaches have been employed to study imprinted genes and their function. Standard constitutive deletion models provide key insights into gene function and have been critical for identifying intrinsic roles of imprinted genes in regulating metabolism. However, they are limited by the nature of imprinted genes, whereby heterozygous mutations present as functionally null and are frequently associated with a wide range of both developmental and adult pathologies, and with at least some degree of mortality. In a distinct approach from more standard gene deletion models that target the coding region of a gene, a number of mouse models have been generated whereby the ICR, where differential methylation is normally found, is deleted. These deletions have often been designed to mimic those changes seen in human disease, with the resulting absence of epigenetic marks modulating the expression of some or all the genes within an imprinted cluster, producing both loss of expression and loss of imprinting (biallelic expression) within the affected cluster [32,33]. Transgenic mouse lines, whereby additional copies of imprinted genes are expressed from a vector such as a bacterial artificial chromosome (BAC), allow the consequences of elevating imprinted gene dosage to be studied. Thus, modeling 'loss of imprinting' can frequently be used to elegantly contrast with loss of expression observations. Limitations to this approach centre on the already discussed complexities associated with multiple layers of epigenetic control and the chromosomal clustering of these genes. As a result, expression from these transgenes often only loosely recapitulates endogenous expression, due in part to missing distant regulatory elements on the vector, and altered expression of some, but not all genes found within an imprinted cluster. Furthermore, it should be noted that monoallelic expression and tissue distribution of certain imprinted genes, i.e. Grb10/GRB10 are not always similarly regulated in mice and humans [34-38]. That being said, these genetic approaches in mice have been instrumental in identifying roles for a number of imprinted clusters and are generally at their most persuasive when used in conjunction with one 
another, to provide a more complete picture of specific gene function within an imprinted cluster.

As previously mentioned, perhaps the most prominent feature of imprinted genes is their relative enrichment of expression in fetal and placental tissue and their potency for modulating in utero growth potential. Abnormal growth and development in these early prenatal and/or postnatal periods due to genetic (imprinted gene mis-expression) or environmental causes (such as reduced or excessive nutrient availability) are itself strongly associated with the risk of developing metabolic disease in later life [39, 40]. This phenomenon is both interesting in a biological sense and also strongly influences how we assess adult metabolic health. However, it adds another layer of complexity to studying the function of imprinted genes and their contribution to the effects observed upon their deletion. Without the use of inducible imprinted gene deletion, it is difficult to distinguish whether metabolic phenotypes arising in adulthood are due to alterations in growth and developmental in early life, or whether the absence of imprinted gene expression is sufficient to drive metabolic phenotypes in adulthood alone. Here, we will discuss the current understanding of imprinted genes and their physiological importance, with an emphasis on their contribution to growth and metabolism at various stages of postnatal mammalian lifespan.

\section{Control of fetal growth and placental resources}

Although this review will focus on the influence of imprinted genes on growth and metabolism after birth, it is important to at least mention the contribution of these genes in utero. A crucial structure in mammalian prenatal development, the placenta acts as a boundary between the mother and the developing fetus and is essential for hormone transport, immunity to environmental pathogens and as a source of nutrients and growth factors. A significant number of imprinted genes are expressed in the placenta itself, with the importance of their dosage in the placenta demonstrated by the finding that loss of function or loss of imprinting of several genes causes severe placental abnormalities and subsequent fetal growth defects or even lethality. For example, disruption of placental Ascl2, Phlda2 or Cdknlc results in placental structural abnormalities and perturbed placental and fetal growth [41-46]. Other imprinted genes modulate fetal growth via an effect in both placental and embryonic tissues including Grblo and $D l k 1$ [47-51] as well as the $I g f 2$ and $I g f 2 r$ system [52-54]. In this latter example, dual growth promoting effects from placenta and fetus were demonstrated by the fact that fetal growth restriction caused by placental-specific knockout of $I g f 2$ was worsened upon global deletion of $\operatorname{Ig} f 2$ [55]. These in utero interactions have been reviewed in detail $[15,20,56]$ and so herein we will focus on the effects of imprinted gene expression on modulating growth and metabolism from birth onwards.

\section{Thriving in the neonatal nesting period}

Imprinted gene expression frequently extends into the neonatal and postnatal stages, regulating growth and metabolism after birth. This stage of life represents a period when there is a necessity for a combination of both behavioural actions from the pup, with its demand for nutrients (from the mother's milk) to enable both growth and the rapid laying down of fat stores, and also to keep warm in the nest prior to full independent thermoregulation. On the other hand, maternal instincts that allow sufficient nurturing of the newborn (feeding, milk production, nest building) are of equal importance. Again, here, imprinted genes are at the centre of this crucial phase of life, and are discussed below (also see Fig. 1 for summary).

\section{Offspring thermoregulation and feeding behaviour}

Discussed below are some of the contributions of imprinted gene function based on either metabolic or behavioural effects in the neonatal period (Fig. 1). In the pup, deletion of exon 1 at the Gnas locus and disruption of XLas in the same cluster lead to impaired suckling, resulting in high neonatal lethality [23]. Similarly, paternal disruption of Magel2 results in reduced postnatal viability with reduced appetite and a failure to suckle $[24,57,58]$. Also intrinsic to the pup, deletion of the paternally expressed gene Peg3 renders them chronically hypothermic and less able to defend their body temperature under cold challenge [59]. Disruption or overexpression of the paternally expressed gene $D l k l$ results in fetal and postnatal growth restriction or overgrowth, respectively, with both genetic manipulations associated with partial neonatal lethality [50,51]. Also found at this locus, and controlled by the same shared ICR, disruption of the paternally expressed gene Dio3 leads to partial embryonic lethality and is associated with thyrotoxicosis $[60,61]$. Postnatally, disruption of the ICR at this cluster that modifies both Dlk1 and Dio3 dosage, amongst others, impacts upon the development of brown adipose tissue (BAT) and therefore appropriate control of thermogenesis outside of the nest and subsequent postnatal survival [26]. Huddling for warmth is a simple cooperative behaviour observed in many species, in which the costs of heat production are borne by the individual but the benefits are shared. Under the paternal conflict theory, maternally expressed genes would favour increased thermogenic contribution, while paternally expressed genes would act to restrict this process, and although some imprinted genes hold firm to this (Grb10, 
Fig. 1 Surviving the neonatal nesting period requires multiple behavioural and metabolic inputs from both mother and pup. PEGs and MEGs that are functionally relevant to each process are displayed in green and red, respectively

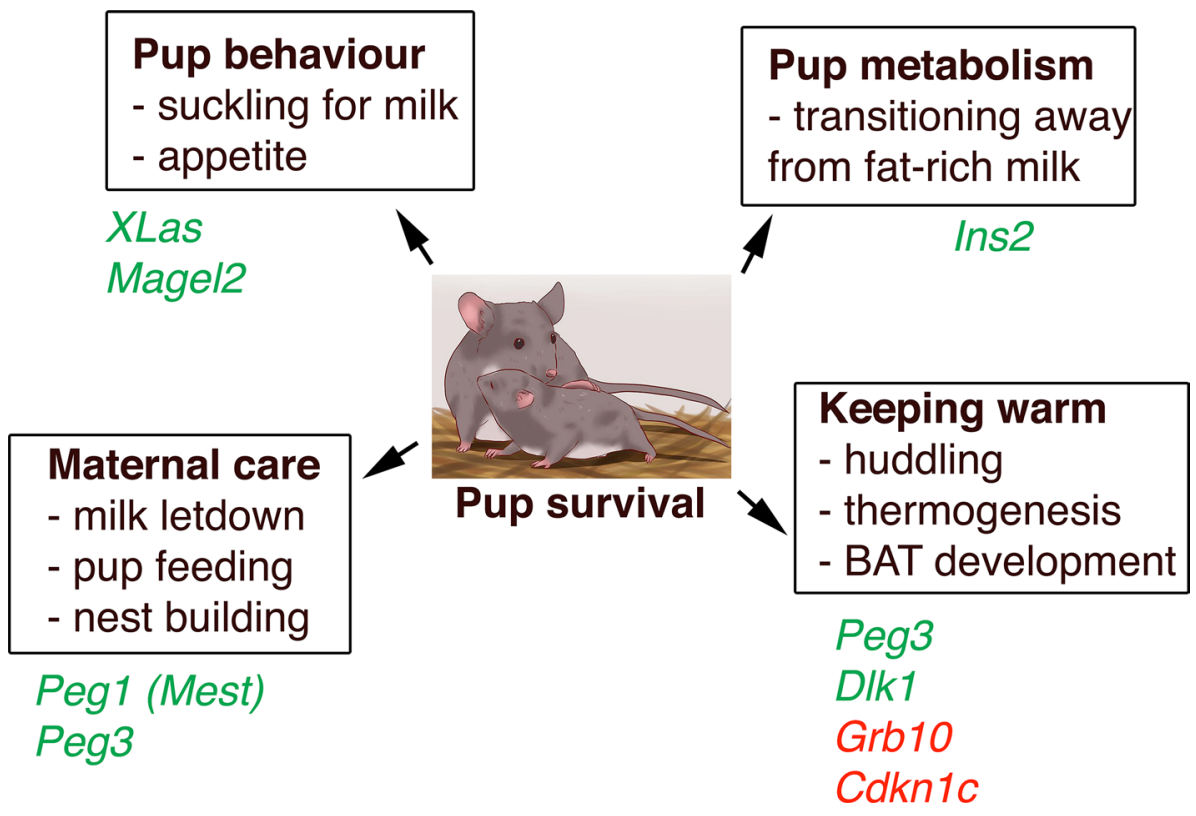

Cdknlc and Dlkl) [26, 29, 62], exceptions to this trend have been observed (Peg3) [59].

\section{Maternal-fetal interactions and the co-adaptation model}

Paternally expressed genes Pegl (Mest) and Peg3 are strongly expressed in the developing postnatal brain and, when mutated, result in compromised maternal care in mutant nursing mothers. Specifically, this includes reduced nest building and pup care with reduced maternal food intake and impaired milk letdown [21, 22, 63]. Disruption of either of these genes in the mother culminates in reduced pup survival, even if offspring are wild type and therefore display no other growth impairments. A large number of imprinted gene deletion models adhere to the parental conflict model, whereby ablation of paternally expressed genes leads to growth defects, while ablation of maternally expressed genes leads to early overgrowth. However, although a large portion of imprinted gene functions fit with this model, there are a significant number that do not clearly adhere to these rules, and this is particularly apparent when observing maternal care paradigms.

The co-adaptation model [12] puts forward the idea that genomic imprinting arose to establish a form of genetic symbiosis between mother and offspring, where imprinted gene function acts at both the level of the mother and in offspring interaction, with silencing of one copy able to benefit offspring vigor by modulating both organisms. This occurs with the imprinted gene Grblo, which is unique in the sense that it is maternally expressed in peripheral tissues but paternally expressed in the CNS under a brain-specific promoter [37, 48]. Accordingly, paternal uniparental disomy
(UPD) or maternal Grb10 deletion results in prenatal and postnatal $(\sim 130 \%)$ overgrowth, but with a disproportionately small brain and large liver [47, 48, 64]. Additionally, these mutants display major physiological alterations in peripheral tissues including perturbed BAT-mediated thermogenesis, increased lean mass, reduced adiposity and improved glucose metabolism [37, 62, 64-66]. Inversely, paternal Grb10 expression within the CNS appears to be more important at the behavioural level, with paternal deletion resulting in increased social dominance [37]. Gene deletion studies also demonstrate the contribution of Grb10 expression in the mother and from the pup. Disruption of maternal Grb10 expression in the pup appears to increase nutrient demand from the offspring, whereas maternal Grb10 deficiency in the mother prevents any increase in milk supply from the ducts (where Grblo is also imprinted) under these conditions of increased demand. Therefore, Grb10 regulates offspring growth and adiposity by mediating both sides of the mother-offspring interaction [67].

\section{Post-weaning catch up growth and adult metabolic complications}

The transition to independent life involves crucial physiological requirements such as maintaining core body temperature outside of the nest, as described above. This postnatal period also requires the offspring to begin to acquire food other than that provided by their mother, with concomitant impacts upon the regulation of their metabolism. This requires a major metabolic shift, as the pup transfers from a lipid-rich milk-based source of nutrients from its mother, to a carbohydrate-rich diet $[26,68]$. This shift from a generally lipolytic metabolism to a lipogenic one coincides with the 
deposition of white adipose tissue (WAT) in the postnatal period (Fig. 2). Insulin, a key anabolic hormone required for sufficient adipose tissue accumulation, plays a more important role in the postnatal rather than prenatal period in mice. This is demonstrated by the fact that deletion of both major forms of insulin in rodents, Ins2 (imprinted during the gestational period but with biallelic expression postnatally) and Ins1 (non-imprinted), or ablating the insulin receptor Insr, does not cause any major growth or metabolic perturbations to glucose homeostasis in utero. However, these mutants develop rapid neonatal diabetes soon after birth [69-72].

The paternally expressed imprinted gene, Plagll, is located in a genomic region associated with transient neonatal diabetes in humans, caused by either paternal UPD of chromosome 6 or duplication of this region [73]. This effect is phenocopied in mice with overexpression of Plagll, recreating this neonatal hyperglycaemia observed in affected children [74]. Similarly, Rasgrfl is a paternally expressed gene found primarily in the postnatal brain and pancreatic beta cells. Mice null for Rasgrfl on the paternal allele are postnatally growth restricted which continues into adulthood. In adulthood they also present with hypoinsulinaemia from reduced beta cell mass (due to reduced beta cell neogenesis and proliferation) and, therefore, demonstrate impaired glucose tolerance $[75,76]$.

Abnormal growth in the postnatal period (Fig. 2), due to genetic or environmental causes (such as reduced or excessive nutrient availability), influences key processes governing feeding and energy homeostasis in early adulthood. As such, these defects are strongly associated with the risk of developing obesity and metabolic disease in late adulthood [39, 40, 77]. This occurs when a developing organism responds to substandard environmental conditions during early stage programming. Ultimately, this leads to an increased risk of developing the metabolic syndrome in later life, a phenomenon known as metabolic programming that falls within the wider phenomena of fetal programming [78, 79] (Fig. 2; Table 1). Proposed mechanisms for how this early life adversity can be detrimental to long-term metabolic health include permanent changes in organ structure and programmed and sustained epigenetic changes in gene expression [80, 81]. Altered imprinted gene dosage for various paternally expressed genes is, therefore, a risk factor for obesity in adulthood. Deficiency of $N d n$ or overexpression of Pegl (Mest) in mice causes obesity owing to increases in adipose tissue expansion [82-84]. Brain-specific deletion of $G s a$, which controls melanocortin-mediated energy expenditure in the hypothalamus, results in hypometabolism and obesity with associated glucose intolerance and insulin resistance [25, 85-87]. There are, however, cases where failure to thrive in the postnatal period does not necessarily lead to obesity and the metabolic syndrome in adulthood. Pups with disruption of XLas that survive to adulthood are severely growth restricted, lean, with an increased metabolic rate and are hypersensitive to insulin, and display an associated hyperphagic phenotype [23, 28]. Similarly, although

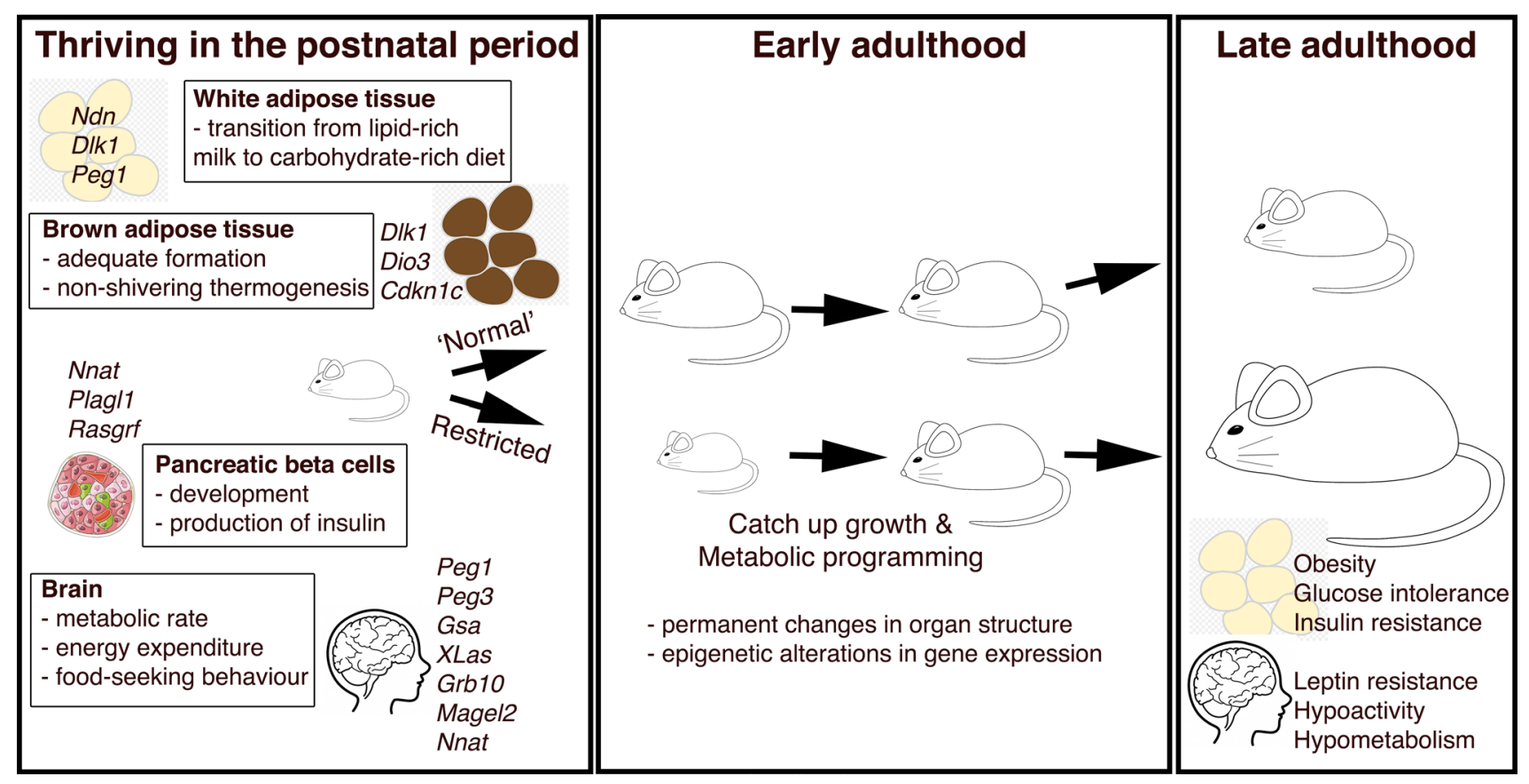

Fig. 2 Progression to independent postnatal life requires adequate development and functionality in multiple metabolic systems. Furthermore, restricting growth and development at this crucial early stage results in metabolic programming and thus metabolic complications in adulthood 


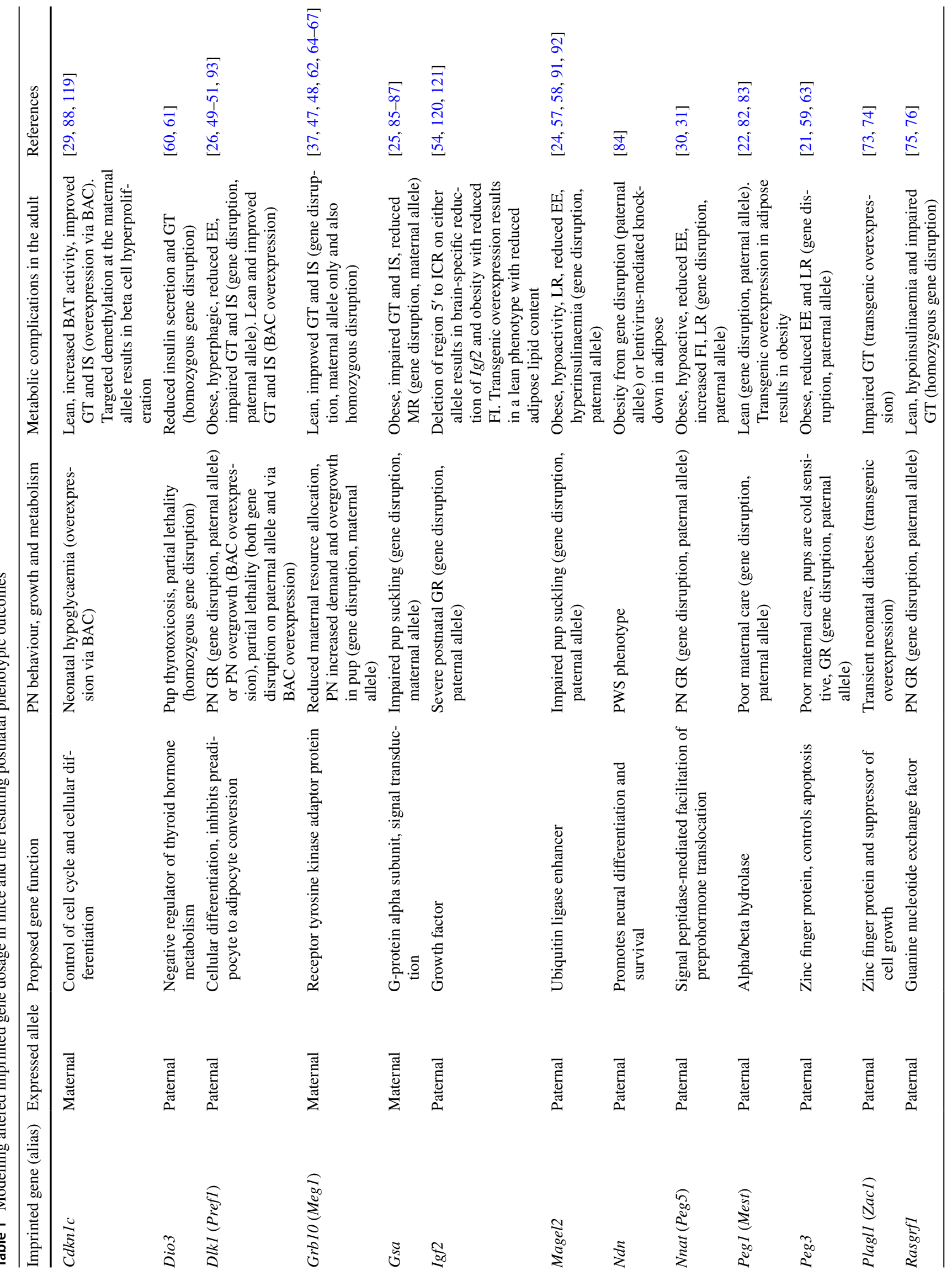


maternal duplication and, therefore, biallelic expression of $C d k n 1 c$ in mice phenocopies Silver-Russell Syndrome with low birth weight and neonatal hypoglycaemia, these early defects result in leanness in adults, due principally to browning of WAT. These animals are also protected from diet- and age-induced obesity, and the associated worsening of glucose tolerance and insulin sensitivity. A specific role for modulation of the brown adipocyte lineage is also implicated in Cdknlc loss of function studies, with the null mice displaying a failure of BAT formation [29, 88].

Overall, these mouse models with altered expression of imprinted genes demonstrate a failure to thrive in the early postnatal period, mimicking the pattern observed in human imprinting disorders such as Prader-Willi and Silver-Russell syndrome $[89,90]$ (summarised in Table 1). A common feature of these early defects is a postnatal 'catch up' growth phase following this failure to thrive period. Nnat (Peg5) is not expressed in the placenta and does not alter fetal growth, but its deletion causes a postnatal growth restriction and subsequent catch up growth following weaning [30]. This catch up growth acts to reestablish the growth of an organism back to its 'normal' trajectory (reviewed in [39]) and is frequently found after manipulation of imprinted gene dosage in mutant mice, often in the neonatal and/or postnatal period, where mice are transitioning to leaving the nest (reviewed in [15]). In adulthood, Nnat null mutants have lower energy expenditure and are hypoactive, leptin resistant and hyperphagic, which together lead to the development of obesity [30]. Obesity also results from deletion of paternally expressed genes Peg3, Dlk1 or Magel2, with differences in feeding and energy expenditure, all of which exhibit early postnatal catch up growth in the null allele of each gene [24, $51,57,59]$. Magel2 mutation is associated with a postnatal failure to thrive, with pups that reach weaning age developing obesity and hyperinsulinaemia, with associated reduced energy expenditure, even in the face of hypophagia and hypoactivity [57, 58, 91, 92]. Although displaying reduced survival as pups, $\mathrm{Peg} 3$ null mice that survive to early adulthood are underweight and hypophagic with delayed postnatal adipose deposition, but with elevated adiposity in later life. This is due to hypothalamic dysregulation manifesting as reduced metabolic rate and core body temperature and also leptin resistance [59, 63]. Mice with altered expression of $D l k l$ have postnatal growth defects with partial lethality [49, 51]. Mutant mice surviving until weaning demonstrate postnatal catch up growth and increased adiposity on both normal and high fat diet [49, 51]. Conversely, mice with transgenic Dlkl overexpression, although displaying increased prenatal growth, also show partial lethality due to major organ abnormalities [50]. Surviving adults, however, have reduced adult 
adiposity and resistance to high fat diet, with improved glucose tolerance and insulin resistance [93].

\section{Imprinted gene modulation in response to the environment}

Our increased understanding of imprinted genes has revealed a multitude of functions that extend beyond the in utero period, regulating growth potential, resource allocation and metabolism from an early stage embryo through to adulthood and into later life. Primary epigenetic marks, including differential DNA methylation of the ICRs that regulate imprinted genes, are laid down in the respective germlines and maintained throughout lifespan of the individual. While these marks are believed to initiate monoallelic expression, secondary imprinting marks, which can also include DNA methylation but extend to modification of histone tails and chromatin architecture, are established post-fertilisation and are thought to help retain the correct expression of the gene or cluster. It has been shown in numerous experiments that epigenetic marks can be susceptible to environmental modulation [94-101]. One could, therefore, hypothesize that imprinted genes would be environmentally sensitive as a group, due to the requirement of these epigenetic marks to ensure appropriate allelic expression. These marks are laid down in utero, either via the methylation of the ICRs in the newly formed germ cells of the embryo, or via secondary imprinting marks in the developing somatic tissues. This would, therefore, suggest that the in utero period provides a key window for environment-dependent programming of imprinted gene expression.

An early study into this potential sensitivity showed that the ICRs as a group were insensitive in offspring that had been exposed to gestational protein restriction [102]. The authors did, however, note that there were some modest changes in the expression of those imprinted genes analysed. More recently, studies have shown that the putative secondary imprinting marks may in fact show some environmental sensitivity [94]. The clearest indication of this response was demonstrated by a new approach to studying imprinted genes, where a firefly luciferase knock-in model was used to image allelic expression of the $C d k n l c$ gene. Upon gestational low protein exposure, a loss of imprinting occurred whereby exposed embryos were found to have active transcription of the $C d k n l c$ gene from both of the parentally inherited alleles, which was retained into adulthood. These changes were found to be caused by gestational erosion of differential DNA methylation of a region spanning the Cdknlc promoter, a secondary imprinting mark that usually retains silencing of the paternal allele. Perhaps most interestingly, these changes could be largely buffered against by the supplementation of dietary folate, indicating that the limited availability of dietary methyl donors was the cause of these epigenetic changes [94].

While studies have shown that as a group imprinted genes show no specific responsiveness to environmental modulation [103], it remains most likely that certain imprinted loci are sensitive to specific stimuli. The reasons for this selective sensitivity, or the phenotypic consequences of the resulting expression changes, are not currently understood. However, the different mouse models of imprinted gene modulation that have so-far been discussed would suggest that any changes are likely to be profound and lifelong. A recent study using haploinsufficiency of the epigenetic modifier Trim 28 demonstrated that imprinted gene dysregulation can provide a clear indicator of metabolic fitness, and these observations appeared to be closely re-capitulated in cohorts of obese children [104]. It should also be noted that due to the unique epigenetic regulation that imprinted genes undergo, with the establishment of methylation marks in the developing germlines, any sensitivity of these marks to environmental pressures in pregnancy has the potential to directly influence both the F1 and F2 generations. However, studies concerning multi-generational and trans-generational effects on imprinted genes have, until now, provided somewhat conflicting data [105-109]. The extent of environmental sensitivity of this group of genes will only truly be established through further well-controlled studies.

\section{Concluding remarks}

Imprinted genes function in multiple cellular pathways but their roles appear to converge on postnatal processes that modulate early growth and behaviour. Unsurprisingly, genetic deletion in mice has proved to be a major source of knowledge in terms of imprinted gene function (Table 1), although the organisation of imprinted genes into genomic clusters often makes the design or analysis of these mutant mouse models difficult. However, these null alleles have been crucial to our understanding of imprinted gene function. Transgenic models expressing more than one active allele and, therefore, modelling loss of imprinting often results in severe phenotypic outcomes and so provide evidence for the evolutionary impetus behind the reduced dosage of imprinted genes in a particular organism. Imprinted genes are expressed in the fetus and placenta during gestation and, clearly, are important for placental function and embryonic growth [1-3]. The fact that the development of genomic imprinting appears to have coincided with the appearance of the placenta in evolution strongly suggests an interrelated role for both the regulation of the supply and demands of nutrients in utero $[5,11,110]$. However, it has 
also been suggested that genomic imprinting arose as a result of co-adaptation between the mother and her offspring to achieve optimal fitness for both via placental resource allocation in utero and via lactation in the nesting period [12, 111].

Without information from inducible deletion mouse models, where imprinted gene expression is retained in early life and deleted in adulthood, it has been challenging to tease apart the relative contributions of imprinted genes in early life and adulthood. However, as has been described, a growing number of direct functional roles have been assigned to imprinted gene expression in adult metabolic tissues. Whether there is added evolutionary impetus for genes to be imprinted as they affect adult metabolism either directly or indirectly remains unclear. Certainly, it can be said that using current hypotheses for why imprinting arose in mammals, it is challenging to explain many of the observed effects in adult tissues of transgenic mice. It remains likely that the initial driving force for the appearance of the imprinting system arose alongside the emergence of the mammalian pregnancy, and not due to any potential benefits observed in adult tissue. That is not to say that evolutionary pressure centering on adult metabolic tissues has not been a key driving force for the subsequent expansion of the imprinting system that has occurred with the mammalian phylogenic evolution.

Failure to thrive in infancy leads to complications in adulthood (Table 1). The postnatal period requires a combination of behavioural (suckling for milk) and metabolic (independent thermoregulation) actions in the offspring as well as sufficient maternal care (feeding, milk production, nest building), with imprinted genes central to these processes. Postnatal offspring are then required to begin to seek food other than that provided by their mother and subsequently shift their internal metabolism to a lipogenic directionality, coinciding with an increase in adipose tissue stores. A failure to thrive in this crucial period, marked by phenotypic features such as postnatal growth restriction and early metabolic defects, permanently alters developmental trajectories in the offspring. These alterations in fat deposition and hypothalamic circuitry lead to metabolic complications in the adult, often in the form of obesity, as a direct result of phenotypes such as hyperphagia, reduced energy expenditure and leptin resistance. Ultimately, obesity is the cause of multiple secondary metabolic disorders in the periphery such as reduced glucose uptake and insulin resistance. However, a restriction to proper adipose expansion is itself a driver of the metabolic syndrome, as the inability to store potentially toxic lipids in inert adipose tissues leads to their deposition in more sensitive peripheral organs including muscle and liver [112].

An array of metabolic disorders stems from inappropriate expression levels of imprinted genes [85, 89, 90, 113-117]. With a greater understanding of imprinted gene function, we are now beginning to see that these effects are both indirect, through early life programming, and direct in adult tissues, with subtle modulations in expression capable of inducing profound phenotypic consequences. Imprinted genes, therefore, present as an interesting and novel target for pharmaceutical intervention in metabolic disease. Due to their wellcharacterised epigenetic regulation, targeted therapies have the potential to "reprogramme" desired tissues, with early studies indicating great potential for this route [118]. As more functional roles are uncovered, so the interest in this group of genes will continue.

Acknowledgements Work in the D.J.W. lab was supported by a Wellcome Trust Project Grant (093082/Z/10/Z), a Wellcome Trust Strategic Award (098565/Z/12/Z) and funding from the Medical Research Council (MC-A654-5QB40). M.V.d.P. was supported by an Imperial College/Wellcome Trust ISSF Fellowship (PS3125_WCMA).

\section{Compliance with ethical standards}

Conflict of interest The authors declare no conflict of interest.

Open Access This article is distributed under the terms of the Creative Commons Attribution 4.0 International License (http://creativeco mmons.org/licenses/by/4.0/), which permits unrestricted use, distribution, and reproduction in any medium, provided you give appropriate credit to the original author(s) and the source, provide a link to the Creative Commons license, and indicate if changes were made.

\section{References}

1. Surani MA (1994) Genomic imprinting: control of gene expression by epigenetic inheritance. Curr Opin Cell Biol 6:390-395

2. Surani MA, Barton SC, Norris ML (1984) Development of reconstituted mouse eggs suggests imprinting of the genome during gametogenesis. Nature 308:548-550

3. McGrath J, Solter D (1983) Nuclear transplantation in the mouse embryo by microsurgery and cell fusion. Science 220:1300-1302

4. Ferguson-Smith AC (2011) Genomic imprinting: the emergence of an epigenetic paradigm. Nat Rev Genet 12:565-575

5. Reik W, Walter J (2001) Genomic imprinting: parental influence on the genome. Nat Rev Genet 2:21-32

6. Bartolomei MS, Ferguson-Smith AC (2011) Mammalian genomic imprinting. Cold Spring Harb Perspect Biol. https:// doi.org/10.1101/cshperspect.a002592

7. Plasschaert RN, Bartolomei MS (2014) Genomic imprinting in development, growth, behavior and stem cells. Development 141:1805-1813

8. Radford EJ, Ferron SR, Ferguson-Smith AC (2011) Genomic imprinting as an adaptative model of developmental plasticity. FEBS Lett 585:2059-2066

9. Tucci V, Isles AR, Kelsey G, Ferguson-Smith AC, Erice Imprinting $\mathrm{G}$ (2019) Genomic imprinting and physiological processes in mammals. Cell 176:952-965

10. Moore T, Haig D (1991) Genomic imprinting in mammalian development: a parental tug-of-war. Trends Genet 7:45-49

11. Haig D (2004) Genomic imprinting and kinship: how good is the evidence? Annu Rev Genet 38:553-585 
12. Wolf JB, Hager R (2006) A maternal-offspring coadaptation theory for the evolution of genomic imprinting. PLoS Biol 4:e380

13. Pires ND, Grossniklaus U (2014) Different yet similar: evolution of imprinting in flowering plants and mammals. F1000Prime Rep 6:63

14. Koski LB, Sasaki E, Roberts RD, Gibson J, Etches RJ (2000) Monoalleleic transcription of the insulin-like growth factor-II gene (Igf2) in chick embryos. Mol Reprod Dev 56:345-352

15. Peters $\mathbf{J}$ (2014) The role of genomic imprinting in biology and disease: an expanding view. Nat Rev Genet 15:517-530

16. Soellner L, Begemann M, Mackay DJ, Gronskov K, Tumer Z, Maher ER, Temple IK, Monk D, Riccio A, Linglart A, Netchine I, Eggermann T (2017) Recent advances in imprinting disorders. Clin Genet 91:3-13

17. Morison IM, Reeve AE (1998) A catalogue of imprinted genes and parent-of-origin effects in humans and animals. Hum Mol Genet 7:1599-1609

18. Tycko B, Morison IM (2002) Physiological functions of imprinted genes. J Cell Physiol 192:245-258

19. Tunster SJ, Jensen AB, John RM (2013) Imprinted genes in mouse placental development and the regulation of fetal energy stores. Reproduction 145:R117-R137

20. Cleaton MA, Edwards CA, Ferguson-Smith AC (2014) Phenotypic outcomes of imprinted gene models in mice: elucidation of pre- and postnatal functions of imprinted genes. Annu Rev Genom Hum Genet 15:93-126

21. Curley JP, Barton S, Surani A, Keverne EB (2004) Coadaptation in mother and infant regulated by a paternally expressed imprinted gene. Proc Biol Sci 271:1303-1309

22. Lefebvre L, Viville S, Barton SC, Ishino F, Keverne EB, Surani MA (1998) Abnormal maternal behaviour and growth retardation associated with loss of the imprinted gene Mest. Nat Genet 20:163-169

23. Plagge A, Gordon E, Dean W, Boiani R, Cinti S, Peters J, Kelsey G (2004) The imprinted signaling protein XL alpha $\mathrm{s}$ is required for postnatal adaptation to feeding. Nat Genet 36:818-826

24. Schaller F, Watrin F, Sturny R, Massacrier A, Szepetowski P, Muscatelli F (2010) A single postnatal injection of oxytocin rescues the lethal feeding behaviour in mouse newborns deficient for the imprinted Magel2 gene. Hum Mol Genet 19:4895-4905

25. Chen M, Gavrilova O, Liu J, Xie T, Deng C, Nguyen AT, Nackers LM, Lorenzo J, Shen L, Weinstein LS (2005) Alternative Gnas gene products have opposite effects on glucose and lipid metabolism. Proc Natl Acad Sci USA 102:7386-7391

26. Charalambous M, Ferron SR, da Rocha ST, Murray AJ, Rowland T, Ito M, Schuster-Gossler K, Hernandez A, Ferguson-Smith AC (2012) Imprinted gene dosage is critical for the transition to independent life. Cell Metab 15:209-221

27. Ding F, Li HH, Zhang S, Solomon NM, Camper SA, Cohen P, Francke U (2008) SnoRNA Snord116 (Pwcr1/MBII-85) deletion causes growth deficiency and hyperphagia in mice. PLoS One 3:e1709

28. Xie T, Plagge A, Gavrilova O, Pack S, Jou W, Lai EW, Frontera M, Kelsey G, Weinstein LS (2006) The alternative stimulatory G protein alpha-subunit XLalphas is a critical regulator of energy and glucose metabolism and sympathetic nerve activity in adult mice. J Biol Chem 281:18989-18999

29. Van De Pette M, Tunster SJ, McNamara GI, Shelkovnikova T, Millership S, Benson L, Peirson S, Christian M, Vidal-Puig A, John RM (2016) Cdkn1c boosts the development of brown adipose tissue in a murine model of silver russell syndrome. PLoS Genet 12:e1005916

30. Millership SJ, Tunster SJ, Van de Pette M, Choudhury AI, Irvine EE, Christian M, Fisher AG, John RM, Scott J, Withers DJ
(2018) Neuronatin deletion causes postnatal growth restriction and adult obesity in 129S2/Sv mice. Mol Metab 18:97-106

31. Millership SJ, Da Silva Xavier G, Choudhury AI, Bertazzo S, Chabosseau P, Pedroni SM, Irvine EE, Montoya A, Faull P, Taylor WR, Kerr-Conte J, Pattou F, Ferrer J, Christian M, John RM, Latreille M, Liu M, Rutter GA, Scott J, Withers DJ (2018) Neuronatin regulates pancreatic beta cell insulin content and secretion. J Clin Invest 128:3369-3381

32. Lin SP, Youngson N, Takada S, Seitz H, Reik W, Paulsen M, Cavaille J, Ferguson-Smith AC (2003) Asymmetric regulation of imprinting on the maternal and paternal chromosomes at the Dlk1-Gtl2 imprinted cluster on mouse chromosome 12. Nat Genet 35:97-102

33. Oh R, Ho R, Mar L, Gertsenstein M, Paderova J, Hsien J, Squire JA, Higgins MJ, Nagy A, Lefebvre L (2008) Epigenetic and phenotypic consequences of a truncation disrupting the imprinted domain on distal mouse chromosome 7. Mol Cell Biol 28:1092-1103

34. Monk D, Arnaud P, Frost J, Hills FA, Stanier P, Feil R, Moore GE (2009) Reciprocal imprinting of human GRB10 in placental trophoblast and brain: evolutionary conservation of reversed allelic expression. Hum Mol Genet 18:3066-3074

35. Arnaud P, Monk D, Hitchins M, Gordon E, Dean W, Beechey CV, Peters J, Craigen W, Preece M, Stanier P, Moore GE, Kelsey $\mathrm{G}$ (2003) Conserved methylation imprints in the human and mouse GRB10 genes with divergent allelic expression suggests differential reading of the same mark. Hum Mol Genet 12:1005-1019

36. Hikichi T, Kohda T, Kaneko-Ishino T, Ishino F (2003) Imprinting regulation of the murine Meg1/Grb10 and human GRB10 genes; roles of brain-specific promoters and mouse-specific CTCF-binding sites. Nucleic Acids Res 31:1398-1406

37. Garfield AS, Cowley M, Smith FM, Moorwood K, Stewart-Cox JE, Gilroy K, Baker S, Xia J, Dalley JW, Hurst LD, Wilkinson LS, Isles AR, Ward A (2011) Distinct physiological and behavioural functions for parental alleles of imprinted Grb10. Nature 469:534-538

38. Blagitko N, Mergenthaler S, Schulz U, Wollmann HA, Craigen W, Eggermann T, Ropers HH, Kalscheuer VM (2000) Human GRB10 is imprinted and expressed from the paternal and maternal allele in a highly tissue- and isoform-specific fashion. Hum Mol Genet 9:1587-1595

39. McMillen IC, Robinson JS (2005) Developmental origins of the metabolic syndrome: prediction, plasticity, and programming. Physiol Rev 85:571-633

40. Martin-Gronert MS, Ozanne SE (2012) Mechanisms underlying the developmental origins of disease. Rev Endocr Metab Disord 13:85-92

41. Guillemot F, Nagy A, Auerbach A, Rossant J, Joyner AL (1994) Essential role of Mash-2 in extraembryonic development. Nature 371:333-336

42. Tunster SJ, Tycko B, John RM (2010) The imprinted Phlda2 gene regulates extraembryonic energy stores. Mol Cell Biol 30:295-306

43. Tunster SJ, Van De Pette M, John RM (2014) Isolating the role of elevated Phlda2 in asymmetric late fetal growth restriction in mice. Dis Model Mech 7:1185-1191

44. Frank D, Fortino W, Clark L, Musalo R, Wang W, Saxena A, Li CM, Reik W, Ludwig T, Tycko B (2002) Placental overgrowth in mice lacking the imprinted gene Ipl. Proc Natl Acad Sci USA 99:7490-7495

45. Takahashi K, Kobayashi T, Kanayama N (2000) p57(Kip2) regulates the proper development of labyrinthine and spongiotrophoblasts. Mol Hum Reprod 6:1019-1025 
46. Tunster SJ, Van de Pette M, John RM (2011) Fetal overgrowth in the Cdkn1c mouse model of Beckwith-Wiedemann syndrome. Dis Model Mech 4:814-821

47. Charalambous M, Cowley M, Geoghegan F, Smith FM, Radford EJ, Marlow BP, Graham CF, Hurst LD, Ward A (2010) Maternally-inherited Grb10 reduces placental size and efficiency. Dev Biol 337:1-8

48. Charalambous M, Smith FM, Bennett WR, Crew TE, Mackenzie F, Ward A (2003) Disruption of the imprinted Grb10 gene leads to disproportionate overgrowth by an Igf2-independent mechanism. Proc Natl Acad Sci USA 100:8292-8297

49. Cleaton MA, Dent CL, Howard M, Corish JA, Gutteridge I, Sovio U, Gaccioli F, Takahashi N, Bauer SR, Charnock-Jones DS, Powell TL, Smith GC, Ferguson-Smith AC, Charalambous M (2016) Fetus-derived DLK1 is required for maternal metabolic adaptations to pregnancy and is associated with fetal growth restriction. Nat Genet 48:1473-1480

50. da Rocha ST, Charalambous M, Lin SP, Gutteridge I, Ito Y, Gray D, Dean W, Ferguson-Smith AC (2009) Gene dosage effects of the imprinted delta-like homologue 1 (dlk1/pref1) in development: implications for the evolution of imprinting. PLoS Genet 5:e1000392

51. Moon YS, Smas CM, Lee K, Villena JA, Kim KH, Yun EJ, Sul HS (2002) Mice lacking paternally expressed Pref-1/Dlk1 display growth retardation and accelerated adiposity. Mol Cell Biol 22:5585-5592

52. Wang ZQ, Fung MR, Barlow DP, Wagner EF (1994) Regulation of embryonic growth and lysosomal targeting by the imprinted Igf2/Mpr gene. Nature 372:464-467

53. Lau MM, Stewart CE, Liu Z, Bhatt H, Rotwein P, Stewart CL (1994) Loss of the imprinted IGF2/cation-independent mannose 6-phosphate receptor results in fetal overgrowth and perinatal lethality. Genes Dev 8:2953-2963

54. DeChiara TM, Efstratiadis A, Robertson EJ (1990) A growthdeficiency phenotype in heterozygous mice carrying an insulin-like growth factor II gene disrupted by targeting. Nature 345:78-80

55. Constancia M, Hemberger M, Hughes J, Dean W, FergusonSmith A, Fundele R, Stewart F, Kelsey G, Fowden A, Sibley C, Reik W (2002) Placental-specific IGF-II is a major modulator of placental and fetal growth. Nature 417:945-948

56. Smith FM, Garfield AS, Ward A (2006) Regulation of growth and metabolism by imprinted genes. Cytogenet Genome Res 113:279-291

57. Bischof JM, Stewart CL, Wevrick R (2007) Inactivation of the mouse Magel2 gene results in growth abnormalities similar to Prader-Willi syndrome. Hum Mol Genet 16:2713-2719

58. Kozlov SV, Bogenpohl JW, Howell MP, Wevrick R, Panda S, Hogenesch JB, Muglia LJ, Van Gelder RN, Herzog ED, Stewart CL (2007) The imprinted gene Magel2 regulates normal circadian output. Nat Genet 39:1266-1272

59. Curley JP, Pinnock SB, Dickson SL, Thresher R, Miyoshi N, Surani MA, Keverne EB (2005) Increased body fat in mice with a targeted mutation of the paternally expressed imprinted gene Peg3. FASEB J 19:1302-1304

60. Hernandez A, Martinez ME, Fiering S, Galton VA, St Germain D (2006) Type 3 deiodinase is critical for the maturation and function of the thyroid axis. J Clin Invest 116:476-484

61. Medina MC, Molina J, Gadea Y, Fachado A, Murillo M, Simovic G, Pileggi A, Hernandez A, Edlund H, Bianco AC (2011) The thyroid hormone-inactivating type III deiodinase is expressed in mouse and human beta-cells and its targeted inactivation impairs insulin secretion. Endocrinology 152:3717-3727

62. Liu M, Bai J, He S, Villarreal R, Hu D, Zhang C, Yang X, Liang H, Slaga TJ, Yu Y, Zhou Z, Blenis J, Scherer PE, Dong LQ,
Liu F (2014) Grb10 promotes lipolysis and thermogenesis by phosphorylation-dependent feedback inhibition of mTORC1. Cell Metab 19:967-980

63. Li L, Keverne EB, Aparicio SA, Ishino F, Barton SC, Surani MA (1999) Regulation of maternal behavior and offspring growth by paternally expressed Peg3. Science 284:330-333

64. Smith FM, Holt LJ, Garfield AS, Charalambous M, Koumanov F, Perry M, Bazzani R, Sheardown SA, Hegarty BD, Lyons RJ, Cooney GJ, Daly RJ, Ward A (2007) Mice with a disruption of the imprinted Grb10 gene exhibit altered body composition, glucose homeostasis, and insulin signaling during postnatal life. Mol Cell Biol 27:5871-5886

65. Wang L, Balas B, Christ-Roberts CY, Kim RY, Ramos FJ, Kikani CK, Li C, Deng C, Reyna S, Musi N, Dong LQ, DeFronzo RA, Liu F (2007) Peripheral disruption of the Grb10 gene enhances insulin signaling and sensitivity in vivo. Mol Cell Biol 27:6497-6505

66. Holt LJ, Lyons RJ, Ryan AS, Beale SM, Ward A, Cooney GJ, Daly RJ (2009) Dual ablation of Grb10 and Grb14 in mice reveals their combined role in regulation of insulin signaling and glucose homeostasis. Mol Endocrinol 23:1406-1414

67. Cowley M, Garfield AS, Madon-Simon M, Charalambous M, Clarkson RW, Smalley MJ, Kendrick H, Isles AR, Parry AJ, Carney S, Oakey RJ, Heisler LK, Moorwood K, Wolf JB, Ward A (2014) Developmental programming mediated by complementary roles of imprinted Grb10 in mother and pup. PLoS Biol 12:e1001799

68. Herrera E, Amusquivar E (2000) Lipid metabolism in the fetus and the newborn. Diabetes Metab Res Rev 16:202-210

69. Joshi RL, Lamothe B, Cordonnier N, Mesbah K, Monthioux E, Jami J, Bucchini D (1996) Targeted disruption of the insulin receptor gene in the mouse results in neonatal lethality. EMBO J 15:1542-1547

70. Accili D, Drago J, Lee EJ, Johnson MD, Cool MH, Salvatore P, Asico LD, Jose PA, Taylor SI, Westphal H (1996) Early neonatal death in mice homozygous for a null allele of the insulin receptor gene. Nat Genet 12:106-109

71. Duvillie B, Cordonnier N, Deltour L, Dandoy-Dron F, Itier JM, Monthioux E, Jami J, Joshi RL, Bucchini D (1997) Phenotypic alterations in insulin-deficient mutant mice. Proc Natl Acad Sci USA 94:5137-5140

72. Louvi A, Accili D, Efstratiadis A (1997) Growth-promoting interaction of IGF-II with the insulin receptor during mouse embryonic development. Dev Biol 189:33-48

73. Gardner RJ, Mackay DJ, Mungall AJ, Polychronakos C, Siebert R, Shield JP, Temple IK, Robinson DO (2000) An imprinted locus associated with transient neonatal diabetes mellitus. Hum Mol Genet 9:589-596

74. Ma D, Shield JP, Dean W, Leclerc I, Knauf C, Burcelin RR, Rutter GA, Kelsey G (2004) Impaired glucose homeostasis in transgenic mice expressing the human transient neonatal diabetes mellitus locus, TNDM. J Clin Invest 114:339-348

75. Font de Mora J, Esteban LM, Burks DJ, Nunez A, Garces C, Garcia-Barrado MJ, Iglesias-Osma MC, Moratinos J, Ward JM, Santos E (2003) Ras-GRF1 signaling is required for normal beta-cell development and glucose homeostasis. EMBO J 22:3039-3049

76. Clapcott SJ, Peters J, Orban PC, Brambilla R, Graham CF (2003) Two ENU-induced mutations in Rasgrf1 and early mouse growth retardation. Mamm Genome 14:495-505

77. Brodsky D, Christou H (2004) Current concepts in intrauterine growth restriction. J Intensive Care Med 19:307-319

78. Bateson P, Barker D, Clutton-Brock T, Deb D, D'Udine B, Foley RA, Gluckman P, Godfrey K, Kirkwood T, Lahr MM, McNamara J, Metcalfe NB, Monaghan P, Spencer HG, Sultan SE (2004) Developmental plasticity and human health. Nature 430:419-421 
79. Srinivasan M, Patel MS (2008) Metabolic programming in the immediate postnatal period. Trends Endocrinol Metab 19:146-152

80. Bouret SG (2010) Role of early hormonal and nutritional experiences in shaping feeding behavior and hypothalamic development. J Nutr 140:653-657

81. Plagemann A (2005) Perinatal programming and functional teratogenesis: impact on body weight regulation and obesity. Physiol Behav 86:661-668

82. Takahashi M, Kamei Y, Ezaki O (2005) Mest/Peg1 imprinted gene enlarges adipocytes and is a marker of adipocyte size. Am J Physiol Endocrinol Metab 288:E117-E124

83. Nikonova L, Koza RA, Mendoza T, Chao PM, Curley JP, Kozak LP (2008) Mesoderm-specific transcript is associated with fat mass expansion in response to a positive energy balance. FASEB J 22:3925-3937

84. Fujiwara K, Hasegawa K, Ohkumo T, Miyoshi H, Tseng YH, Yoshikawa K (2012) Necdin controls proliferation of white adipocyte progenitor cells. PLoS One 7:e30948

85. Weinstein LS, Xie T, Qasem A, Wang J, Chen M (2010) The role of GNAS and other imprinted genes in the development of obesity. Int J Obes (Lond) 34:6-17

86. Weinstein LS (2014) Role of G(s)alpha in central regulation of energy and glucose metabolism. Horm Metab Res 46:841-844

87. Yu S, Gavrilova O, Chen H, Lee R, Liu J, Pacak K, Parlow AF, Quon MJ, Reitman ML, Weinstein LS (2000) Paternal versus maternal transmission of a stimulatory G-protein alpha subunit knockout produces opposite effects on energy metabolism. J Clin Invest 105:615-623

88. Van de Pette M, Tunster SJ, John RM (2018) Loss of imprinting of Cdkn1c protects against age and diet-induced obesity. Int J Mol Sci 19:E2734

89. Nicholls RD, Ohta T, Gray TA (1999) Genetic abnormalities in Prader-Willi syndrome and lessons from mouse models. Acta Paediatr Suppl 88:99-104

90. Price SM, Stanhope R, Garrett C, Preece MA, Trembath RC (1999) The spectrum of Silver-Russell syndrome: a clinical and molecular genetic study and new diagnostic criteria. J Med Genet $36: 837-842$

91. Pravdivyi I, Ballanyi K, Colmers WF, Wevrick R (2015) Progressive postnatal decline in leptin sensitivity of arcuate hypothalamic neurons in the Magel2-null mouse model of Prader-Willi syndrome. Hum Mol Genet 24:4276-4283

92. Mercer RE, Michaelson SD, Chee MJ, Atallah TA, Wevrick R, Colmers WF (2013) Magel2 is required for leptin-mediated depolarization of POMC neurons in the hypothalamic arcuate nucleus in mice. PLoS Genet 9:e1003207

93. Charalambous M, Da Rocha ST, Radford EJ, Medina-Gomez G, Curran S, Pinnock SB, Ferron SR, Vidal-Puig A, Ferguson-Smith AC (2014) DLK1/PREF1 regulates nutrient metabolism and protects from steatosis. Proc Natl Acad Sci USA 111:16088-16093

94. Van de Pette M, Abbas A, Feytout A, McNamara G, Bruno L, To WK, Dimond A, Sardini A, Webster Z, McGinty J, Paul EJ, Ungless MA, French PMW, Withers DJ, Uren A, Ferguson-Smith AC, Merkenschlager M, John RM, Fisher AG (2017) Visualizing changes in Cdkn1c expression links early-life adversity to imprint mis-regulation in adults. Cell Rep 18:1090-1099

95. Weaver IC, Cervoni N, Champagne FA, D'Alessio AC, Sharma S, Seckl JR, Dymov S, Szyf M, Meaney MJ (2004) Epigenetic programming by maternal behavior. Nat Neurosci 7:847-854

96. Park JH, Stoffers DA, Nicholls RD, Simmons RA (2008) Development of type 2 diabetes following intrauterine growth retardation in rats is associated with progressive epigenetic silencing of Pdx1. J Clin Invest 118:2316-2324

97. Raychaudhuri N, Raychaudhuri S, Thamotharan M, Devaskar SU (2008) Histone code modifications repress glucose transporter 4 expression in the intrauterine growth-restricted offspring. J Biol Chem 283:13611-13626

98. Murgatroyd C, Patchev AV, Wu Y, Micale V, Bockmuhl Y, Fischer D, Holsboer F, Wotjak CT, Almeida OF, Spengler D (2009) Dynamic DNA methylation programs persistent adverse effects of early-life stress. Nat Neurosci 12:1559-1566

99. Sandovici I, Smith NH, Nitert MD, Ackers-Johnson M, UribeLewis S, Ito Y, Jones RH, Marquez VE, Cairns W, Tadayyon M, O’Neill LP, Murrell A, Ling C, Constancia M, Ozanne SE (2011) Maternal diet and aging alter the epigenetic control of a promoter-enhancer interaction at the Hnf4a gene in rat pancreatic islets. Proc Natl Acad Sci USA 108:5449-5454

100. Pogribny IP, Karpf AR, James SR, Melnyk S, Han T, Tryndyak VP (2008) Epigenetic alterations in the brains of Fisher 344 rats induced by long-term administration of folate/methyl-deficient diet. Brain Res 1237:25-34

101. Nohara K, Baba T, Murai H, Kobayashi Y, Suzuki T, Tateishi Y, Matsumoto M, Nishimura N, Sano T (2011) Global DNA methylation in the mouse liver is affected by methyl deficiency and arsenic in a sex-dependent manner. Arch Toxicol 85:653-661

102. Ivanova E, Chen JH, Segonds-Pichon A, Ozanne SE, Kelsey G (2012) DNA methylation at differentially methylated regions of imprinted genes is resistant to developmental programming by maternal nutrition. Epigenetics 7:1200-1210

103. Radford EJ, Isganaitis E, Jimenez-Chillaron J, Schroeder J, Molla M, Andrews S, Didier N, Charalambous M, McEwen K, Marazzi G, Sassoon D, Patti ME, Ferguson-Smith AC (2012) An unbiased assessment of the role of imprinted genes in an intergenerational model of developmental programming. PLoS Genet 8:e1002605

104. Dalgaard K, Landgraf K, Heyne S, Lempradl A, Longinotto J, Gossens K, Ruf M, Orthofer M, Strogantsev R, Selvaraj M, Lu TT, Casas E, Teperino R, Surani MA, Zvetkova I, Rimmington D, Tung YC, Lam B, Larder R, Yeo GS, O'Rahilly S, Vavouri T, Whitelaw E, Penninger JM, Jenuwein T, Cheung CL, Ferguson-Smith AC, Coll AP, Korner A, Pospisilik JA (2016) Trim28 haploinsufficiency triggers bi-stable epigenetic obesity. Cell 164:353-364

105. Jimenez-Chillaron JC, Isganaitis E, Charalambous M, Gesta S, Pentinat-Pelegrin T, Faucette RR, Otis JP, Chow A, Diaz R, Ferguson-Smith A, Patti ME (2009) Intergenerational transmission of glucose intolerance and obesity by in utero undernutrition in mice. Diabetes 58:460-468

106. Stouder C, Paoloni-Giacobino A (2010) Transgenerational effects of the endocrine disruptor vinclozolin on the methylation pattern of imprinted genes in the mouse sperm. Reproduction 139:373-379

107. Stouder C, Paoloni-Giacobino A (2011) Specific transgenerational imprinting effects of the endocrine disruptor methoxychlor on male gametes. Reproduction 141:207-216

108. Dunn GA, Bale TL (2011) Maternal high-fat diet effects on thirdgeneration female body size via the paternal lineage. Endocrinology 152:2228-2236

109. Chamorro-Garcia R, Sahu M, Abbey RJ, Laude J, Pham N, Blumberg B (2013) Transgenerational inheritance of increased fat depot size, stem cell reprogramming, and hepatic steatosis elicited by prenatal exposure to the obesogen tributyltin in mice. Environ Health Perspect 121:359-366

110. Reik W, Constancia M, Fowden A, Anderson N, Dean W, Ferguson-Smith A, Tycko B, Sibley C (2003) Regulation of supply and demand for maternal nutrients in mammals by imprinted genes. J Physiol 547:35-44

111. Keverne EB, Curley JP (2008) Epigenetics, brain evolution and behaviour. Front Neuroendocrinol 29:398-412

112. Rochford JJ (2010) Molecular mechanisms controlling human adipose tissue development: insights from monogenic lipodystrophies. Expert Rev Mol Med 12:e24 
113. Kelly ML, Moir L, Jones L, Whitehill E, Anstee QM, Goldin RD, Hough A, Cheeseman M, Jansson JO, Peters J, Cox RD (2009) A missense mutation in the non-neural G-protein alpha-subunit isoforms modulates susceptibility to obesity. Int J Obes (Lond) 33:507-518

114. Lindsay RS, Kobes S, Knowler WC, Bennett PH, Hanson RL (2001) Genome-wide linkage analysis assessing parent-of-origin effects in the inheritance of type 2 diabetes and BMI in Pima Indians. Diabetes 50:2850-2857

115. Gorlova OY, Amos CI, Wang NW, Shete S, Turner ST, Boerwinkle E (2003) Genetic linkage and imprinting effects on body mass index in children and young adults. Eur J Hum Genet 11:425-432

116. Dong C, Li WD, Geller F, Lei L, Li D, Gorlova OY, Hebebrand J, Amos CI, Nicholls RD, Price RA (2005) Possible genomic imprinting of three human obesity-related genetic loci. Am J Hum Genet 76:427-437

117. Rance KA, Fustin JM, Dalgleish G, Hambly C, Bunger L, Speakman JR (2005) A paternally imprinted QTL for mature body mass on mouse chromosome 8. Mamm Genome 16:567-577

118. Ou K, Yu M, Moss NG, Wang YJ, Wang AW, Nguyen SC, Jiang C, Feleke E, Kameswaran V, Joyce EF, Naji A, Glaser B, Avrahami D, Kaestner KH (2019) Targeted demethylation at the
CDKN1C/p57 locus induces human beta cell replication. J Clin Invest 129:209-214

119. Avrahami D, Li C, Yu M, Jiao Y, Zhang J, Naji A, Ziaie S, Glaser B, Kaestner KH (2014) Targeting the cell cycle inhibitor $\mathrm{p} 57 \mathrm{Kip} 2$ promotes adult human beta cell replication. J Clin Invest 124:670-674

120. Da Costa TH, Williamson DH, Ward A, Bates P, Fisher R, Richardson L, Hill DJ, Robinson IC, Graham CF (1994) High plasma insulin-like growth factor-II and low lipid content in transgenic mice: measurements of lipid metabolism. J Endocrinol 143:433-439

121. Jones BK, Levorse J, Tilghman SM (2001) Deletion of a nuclease-sensitive region between the Igf2 and $\mathrm{H} 19$ genes leads to Igf2 misregulation and increased adiposity. Hum Mol Genet $10: 807-814$

Publisher's Note Springer Nature remains neutral with regard to jurisdictional claims in published maps and institutional affiliations. 